\title{
Catalysts for High Cetane Ethers as Diesel Fuels
}

\author{
Kamil Klier, Richard G. Herman, James G. C. Shen, and Qisheng Ma \\ Zettlemoyer Center for Surface Studies \\ and Department of Chemistry \\ Sinclair Laboratory, 7 Asa Drive \\ Lehigh University \\ Bethlehem, PA 18015
}

Annual Technical Progress Report for September 1, 1999-August 31, 2000

Submitted to the

National Energy Technology Laboratory

Pittsburgh, PA 


\section{Catalysts for High Cetane Ethers as Diesel Fuels}

\section{Disclaimer}

This report was prepared as an account of work sponsored by an agency of the United States Government. Neither the United States Government nor any agency thereof, nor any of their employees, makes any warranty, express or implied, or assumes any legal liability or responsibility for the accuracy, completeness, or usefulness of any information, apparatus, product, or process disclosed, or represents that its use would not infringe privately owned rights. Reference herein to any specific commercial product, process, or service by trade name, trademark, manufacturer, or otherwise does not necessarily constitute or imply its endorsement, recommendation, or favoring by the United States Government or any agency thereof. The views and opinions of authors expressed herein do not necessarily state or reflect those of the United States Government or any agency thereof. 


\title{
Catalysts for High Cetane Ethers as Diesel Fuels
}

\begin{abstract}
A novel 1,2-ethanediol, bis(hydrogen sulfate), disodium salt precursor-based solid acid catalyst with a zirconia substrate was synthesized and demonstrated to have significantly enhanced activity and high selectivity in producing methyl isobutyl ether (MIBE) or isobutene from methanol-isobutanol mixtures. The precursor salt was synthesized and provided by Dr. T. H. Kalantar of the M.E. Pruitt Research Center, Dow Chemical Co., Midland, MI 48674. Molecular modelling of the catalyst synthesis steps and of the alcohol coupling reaction is being carried out. A representation of the methyl transfer from the surface activated methanol molecule (left) to the activated oxygen of the isobutanol molecule (right) to form an ether linkage to yield MIBE is shown below.
\end{abstract}

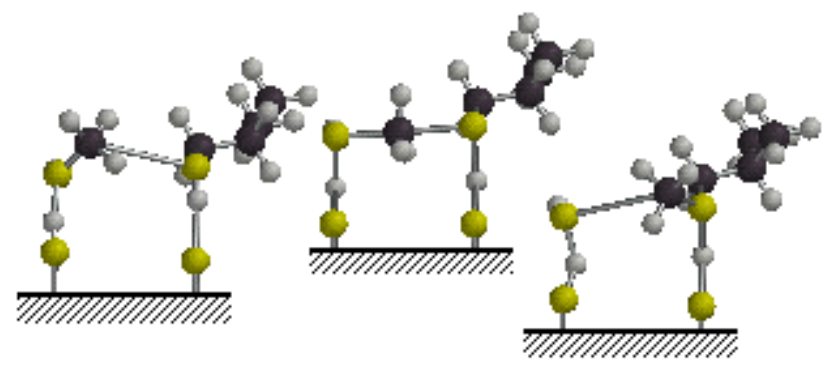




\section{INTRODUCTION}

Methanol and isobutanol are the predominant products formed from $\mathrm{CO} / \mathrm{H}_{2}$ synthesis gas over alkali-promoted $\mathrm{Cu} / \mathrm{ZnO}$-based (low temperature) catalysts $[1,2]$, as well as over copper-free alkali-promoted (high temperature) catalysts $[3,4]$. Since the two alcohols are produced together, their direct coupling to synthesize ethers for a number of applications is of interest. One such ether is the unsymmetrical methylisobutyl ether (MIBE) that has desirable characteristics as a fuel (cetane number $=53$ [5]), and thus, can be employed as an additive to or as a neat fuel to substitute for current diesel fuels [6,7]. MIBE formed by the direct coupling of methanol- isobutanol (Equation 1) was previously investigated over a number of solid acid catalysts [8].

$$
\left(\mathrm{CH}_{3}\right)_{2} \mathrm{CHCH}_{2} \mathrm{OH}+\mathrm{CH}_{3} \mathrm{OH} \int\left(\mathrm{CH}_{3}\right)_{2} \mathrm{CHCH}_{2} \mathrm{OCH}_{3}+\mathrm{H}_{2} \mathrm{O}
$$

Improvement of product yields, particularly over inorganic oxides, was found to be desirable. Furthermore, if new catalysts were found for selectively converting isobutanol to isobutene, Equation 2, a chemical route to isobutene from natural gas or coal-derived synthesis gas would be provided [5].

$$
\left(\mathrm{CH}_{3}\right)_{2} \mathrm{CHCH}_{2} \mathrm{OH} \int\left(\mathrm{CH}_{3}\right)_{2} \mathrm{C}=\mathrm{CH}_{2}+\mathrm{H}_{2} \mathrm{O}
$$

Such a process would alleviate isobutene dependence on petroleum feedstock. The kinetic analyses [8b,9], together with theoretical calculations [10] suggest that the mechanism of Reaction 1 is the $\mathrm{S}_{\mathrm{N}} 2$ pathway involving competitive adsorption of reactants on proximal dual Brrnsted acid sites on the catalyst surface, while that of Reaction 2 has been proposed to be an E2 reaction [8]. Reactions 1 and 2 are a specific 
implementation of a general class of dehydrocondensations and dehydrations occurring in a mixture of a light alcohol and a heavier $\mathrm{C}_{2}$-branched primary alcohol.

In the present work, we studied a novel heterogeneous catalyst derived from a $(\mathrm{HO})_{3} \mathrm{Zr}-\mathrm{O}_{3} \mathrm{SOCH}_{2} \mathrm{CH}_{2} \mathrm{OSO}_{3}-\mathrm{Zr}(\mathrm{OH})_{3}$-type surface precursor that gave rise to proximal strong surface acid functionalities $\left(\mathrm{HOSO}_{2} \mathrm{O}-\mathrm{Zr}-\mathrm{O}-\right)_{2}$ as prompted by the requirement to activate the two alcohols $[8,10]$. Complete characterization of the precursor salt, the synthsized catalyst precursor, and the calcined catalyst before and after use is being carried out. The high resolution X-ray photoelectron (HR-XPS), near infrared (NIR) and ${ }^{13} \mathrm{C}$ magic angle spinning (MAS) nuclear magnetic resonance (NMR) spectra confirmed the composition, structure, and physicochemical properties of the catalyst. The results show that the 1,2-ethanediol, bis(hydrogen sulfate) moiety was successfully grafted onto the surface of zirconium hydroxide, as will be reported in detail in the next technical research report when complete characterization of the catalyst has been accomplished. The main features of the preparation sequence are presented in the scheme shown on the next page. 

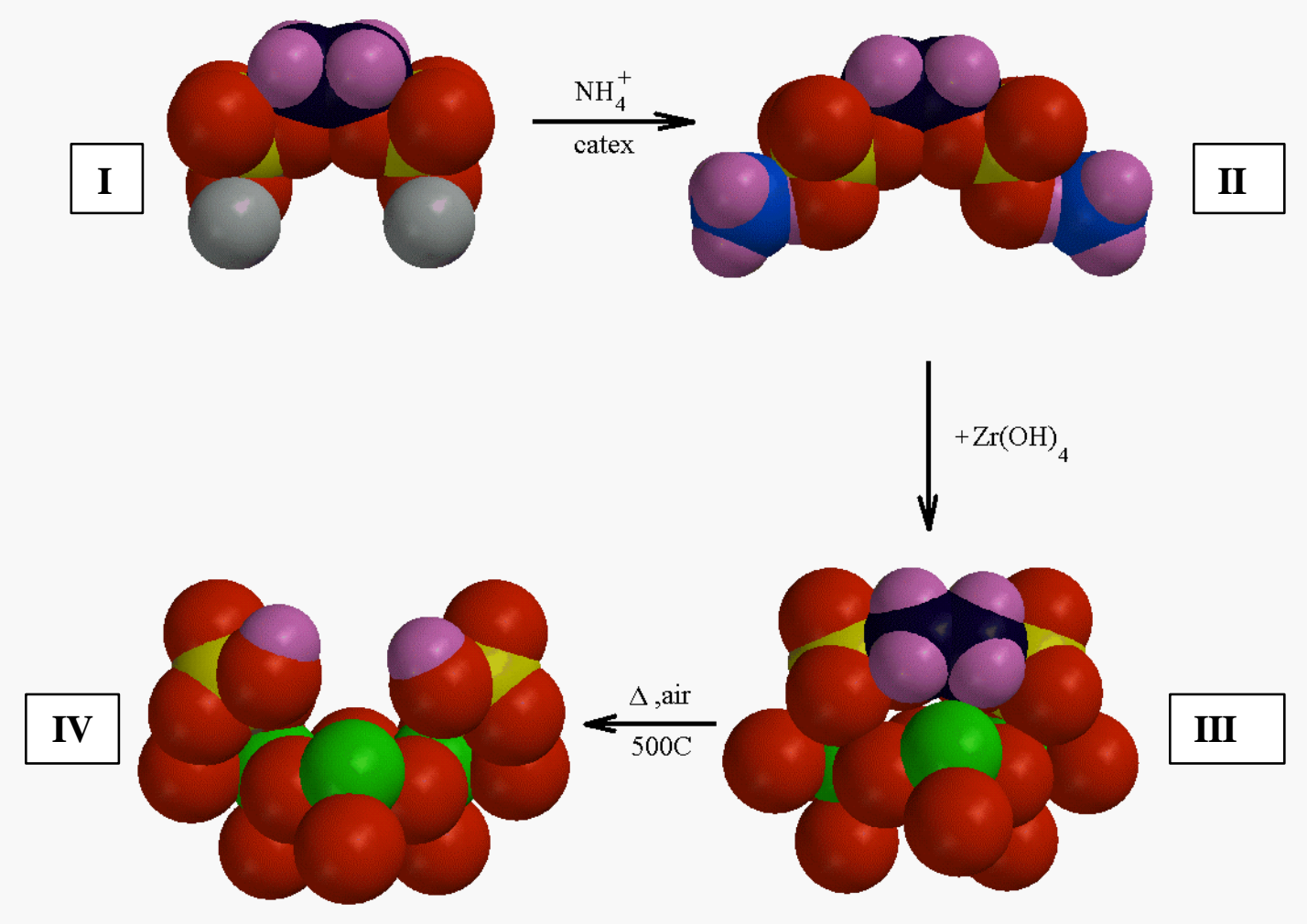

Scheme 1. Color codes for the atoms are as follows: C, black; H, pink; O, red; S, yellow; N, blue, Zr, green; and $\mathrm{Na}$, gray.

\section{EXPERIMENTAL}

The 1,2-ethanediol, bis(hydrogen sulfate), disodium salt precursor I $\left(\mathrm{NaOSO}_{3} \mathrm{CH}_{2}\right)_{2}$ obtained from Dow Chemical Co. was converted to the ammonium form II $\left(\mathbf{N H}_{4} \mathbf{O S O}_{3} \mathbf{C H}_{2}\right)_{2}$ by exchange over a Rexyn 101 catex column, and an aqueous solution of compound II was combined with an aqueous suspension containing zirconium hydroxide to form the derivative III $\left(-\mathbf{O}_{\mathbf{x}} \mathbf{Z r}-\mathbf{O S O}_{3} \mathbf{C H}_{2}\right)_{2}$. This solid was filtered, dried, 
and then calcined in air at $773 \mathrm{~K}$ to remove the $-\left(\mathrm{CH}_{2} \mathrm{CH}_{2}\right)$ - residues, resulting in the surface-derivatized species IV $\left(-\mathbf{O}_{\mathbf{x}} \mathbf{Z r}-\mathbf{O S O}_{3} \mathbf{H}\right)_{2}$, corresponding to proximal acid sites on zirconia. After the calcination treatment, this catalyst exhibited a surface sulfate-tozirconium surface mole ratio of 0.84 , corresponding to $0.72 \mathrm{mmol}$ surface $\mathrm{S} / \mathrm{g}$ cat., and all of the carbon from the precursor was removed. Thus, the final composition corresponds to the formula $\left(\mathrm{HSO}_{4}\right)_{0.84}-\mathrm{ZrO}_{2, \text { surf }}$ on the surface of pure zirconia. This material possessed a high thermal stability.

The coupling/dehydration of methanol-isobutanol (2-methyl-1-propanol, 99.9+\%, Alfa) was investigated in a downflow stainless steel tubular reactor with control of temperature $(398-508 \mathrm{~K})$, total pressure $\left(101.3-3.1 \times 10^{3} \mathrm{kPa}, 1 \mathrm{~atm}=101.325 \mathrm{kPa}\right)$ and i- $\mathrm{BuOH} / \mathrm{MeOH}$ molar ratio $(0 / 100-50 / 50)$ in a carrier gas of $5 \% \mathrm{~N}_{2}$ diluted in He. The catalyst was centered in the vertical reactor in the heated zone by Pyrex beads above and below the bed. A J-type thermocouple was inserted into the top of the bed using an axial stainless steel thermowell. Product analyses were achieved with an on-line HewlettPackard gas chromatograph (Model 5890, Series II) equipped with automated heated sampling valves. A Cpsil-5CB capillary column was used.

\section{CATALYTIC RESULTS}

Maintaining the methanol-isobutanol molar ratio $=1$, the reaction temperature was varied. Table 1 shows that as the temperature was increased, the space time yield of MIBE significantly increased. Also observed were small quantities of dimethylether 
(DME), methyl tertiarybutyl ether (MTBE), diisobutyl ether (DIBE), and ditertiarybutyl ether (DTBE).

Table 1. Product space time yields ( $\mathrm{mol} / \mathrm{kg}$ cat $/ \mathrm{hr}$ ) in the reaction of $\mathrm{MeOH} / \mathrm{i}-\mathrm{BuOH}(1: 1$ molar ratio) with flow rates of $3.44 \mathrm{~mol} / \mathrm{kg} \mathrm{cat} / \mathrm{hr}$ alcohols and $16 \mathrm{~mol} / \mathrm{kgcat} / \mathrm{hr}$ carrier gas at $101.3 \mathrm{kPa}$ total pressure over the $(\mathrm{HO})_{3} \mathrm{Zr}-\mathrm{O}_{3} \mathrm{SOCH}_{2} \mathrm{CH}_{2} \mathrm{OSO}_{3}-\mathrm{Zr}(\mathrm{OH})_{3}$-derived catalyst. $^{\mathrm{a}}$

\begin{tabular}{|c|c|c|c|c|c|c|c|c|c|}
\hline $\begin{array}{c}\text { Temp. } \\
(\mathrm{K})\end{array}$ & $\begin{array}{c}\text { MeOH pressure } \\
(\mathrm{kPa})\end{array}$ & $\begin{array}{l}\text {-BuOH pressure } \\
(\mathrm{kPa})\end{array}$ & MIB & Isob & DME & MTBE & DIBE & DTBE & Octenes \\
\hline 398 & 8.97 & 8.97 & 0.002 & --- & --- & ---- & --- & --- & --- \\
\hline 423 & 8.97 & 8.97 & 0.020 & ---- & ---- & ---- & 0.008 & ---- & 0.004 \\
\hline 448 & 8.97 & 8.97 & 0.087 & 1.430 & ---- & ---- & 0.005 & 0.003 & 0.005 \\
\hline $448^{b}$ & 8.97 & 8.97 & 0.049 & $1.290^{d}$ & 0.103 & 0.007 & ---- & --- & --- \\
\hline $448^{c}$ & 8.97 & 8.97 & 0.029 & $0.378^{d}$ & 0.034 & 0.014 & 0.015 & 0.016 & --- \\
\hline
\end{tabular}

a Steady state activities were readily achieved within $2 \mathrm{hr}$ of initiating alcohol injection or after altering a reaction variable such as temperature. Extended testing of the $(\mathrm{HO})_{3} \mathrm{Zr}-\mathrm{O}_{3} \mathrm{SOCH}_{2} \mathrm{CH}_{2} \mathrm{OSO}_{3}-\mathrm{Zr}(\mathrm{OH})_{3}$-derived catalyst under each condition was performed for 8-12 hr. No catalyst deactivation was observed over several hundreds of hours of testing.

${ }^{b} \mathrm{SO}_{4}{ }^{2-} / \mathrm{ZrO}_{2}$ catalyst [9].

c H-montmorillonite catalyst [9; Table III].

${ }^{\mathrm{d}}$ Butene included isobutene, $\mathrm{n}$ - butene, and cis- and trans-2-butene.

At $448 \mathrm{~K}$, the MIBE yield was $0.087 \mathrm{~mol} / \mathrm{kg}$ cat $/ \mathrm{hr}$, which represented an enhancement of $78 \%$ compared with $0.049 \mathrm{~mol} / \mathrm{kg}$ cat $/ \mathrm{hr}$ over previously reported $\mathrm{SO}_{4}{ }^{2-}$ $/ \mathrm{ZrO}_{2}$ [9], and of $200 \%$ compared with $0.029 \mathrm{~mol} / \mathrm{kg}$ cat $/ \mathrm{hr}$ on an $\mathrm{H}$-montmorillonite catalyst [9]. The isobutene yield of $1.43 \mathrm{~mol} / \mathrm{kg}$ cat $/ \mathrm{hr}$, also observed at $448 \mathrm{~K}$, represented an increase of $11 \%$ and $\sim 280 \%$, respectively, from $1.29 \mathrm{~mol} / \mathrm{kg}$ cat $/ \mathrm{hr}$ on $\mathrm{SO}_{4}{ }^{2-} / \mathrm{ZrO}{ }_{2}$ and $0.378 \mathrm{~mol} / \mathrm{kg}$ cat $/ \mathrm{hr}$ on $\mathrm{H}$ - montmorillonite catalyst [9]. 
Figure 1 shows the effect of $\mathrm{i}-\mathrm{BuOH}$ addition on the production of dimethyl ether (DME) and MIBE. MIBE yields (ם) increased and DME yields (๑) decreased with increasing isobutanol partial pressure. When the ratio of $\mathrm{i}-\mathrm{BuOH} / \mathrm{MeOH}$ reached $12 / 88$, very little DME was observed, resulting in near-100\% selectivity in favor of the unsymmetrical MIBE. This suggests that isobutanol suppressed the DME formation more effectively on this catalyst than on any of the previously studied catalysts $[8,10]$.

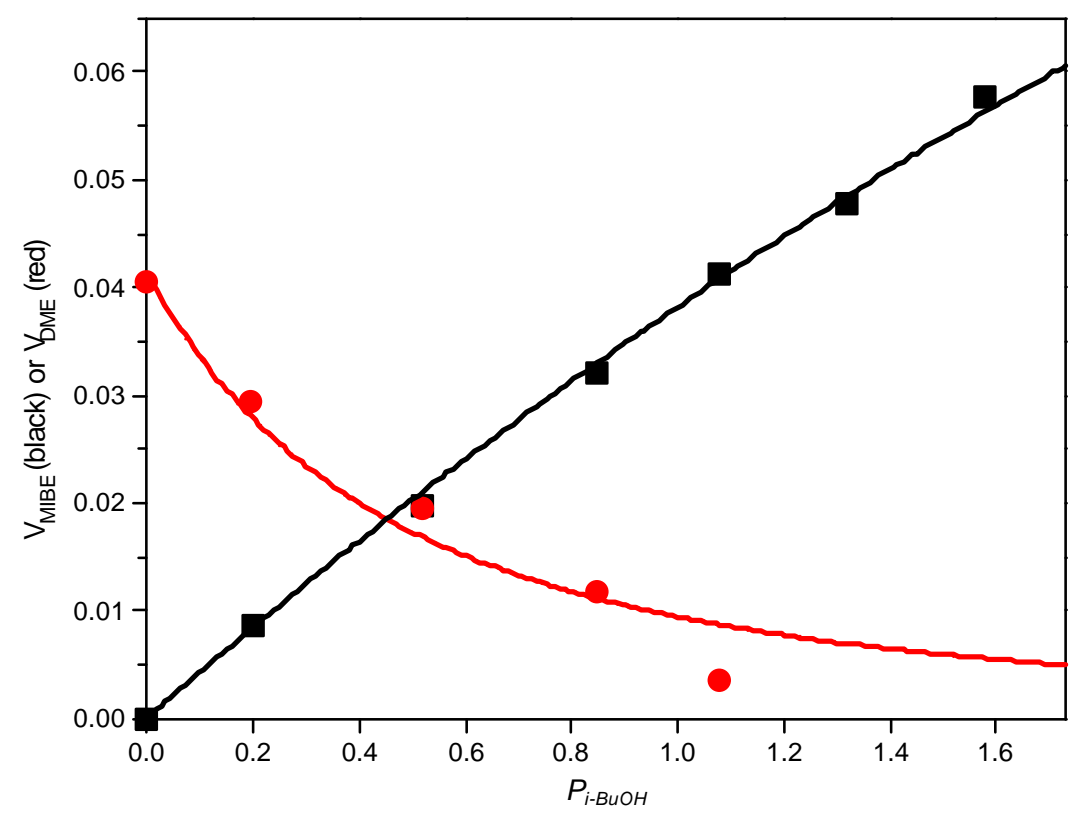

Figure 1. The effect of i-BuOH addition on DME (@) and MIBE (ם) production. The abscissa axis is the partial pressure $P_{\mathrm{I}-\mathrm{BuOH}}$ in $\mathrm{kPa}$ at a constant pressure of methanol $P_{\mathrm{MeOH}}=8.97 \mathrm{kPa}$. The ordinate axis expresses the rates of DME, $\mathrm{v}_{\mathrm{DME}}$, and MIBE, $\mathrm{v}_{\mathrm{MIBE}}$, in $\mathrm{mol} / \mathrm{kg} \mathrm{cat} / \mathrm{hr}$. 
The adsorption constants of $\mathrm{MeOH}\left(K_{\mathrm{M}}\right)$ and $\mathrm{i}-\mathrm{BuOH}\left(K_{\mathrm{B}}\right)$ were determined by curve fitting of the kinetic laws for the DME and MIBE formation [8]. $K_{\mathrm{B}}$ was derived to be $0.086 \mathrm{kPa}^{-1}$ and $K_{\mathrm{M}}$ was found to be $0.035 \mathrm{kPa}^{-1}$. Here, the ratio $K_{\mathrm{B}} / K_{\mathrm{M}}=2.46$ shows that isobutanol adsorbed preferentially on the acid sites, which agrees with its greater basicity over methanol [8b,11]. The distribution of DME and MIBE in Figure 1 can be reasonably explained by kinetics previously observed on other catalysts [8b], with $K_{\mathrm{B}}>$ $K_{\mathrm{M}}$. The experimental data also show increasing yields of isobutene with increased molar ratio of $\mathrm{i}-\mathrm{BuOH} / \mathrm{MeOH}$. In addition, the enhancement of selectivity toward isobutene from $0 \%$ at $398 \mathrm{~K}$ to $94 \%$ at $448 \mathrm{~K}$ (Table 1) results from the increase of $K_{\mathrm{B}} / K_{\mathrm{M}}$ with increasing temperature. The isobutanol dehydration to isobutene competed with $\mathrm{MeOH} / \mathrm{i}-\mathrm{BuOH}$ coupling to MIBE. At relatively high temperatures, a large ratio of $K_{\mathrm{B}} / K_{\mathrm{M}}$ resulted in an enhancement of the $\theta_{\mathrm{i}-\mathrm{BuOH}} / \theta_{\mathrm{MeOH}}$ ratio $(\theta$, surface coverage), which favored the dehydration of the adsorbed isobutanol to isobutene (Equation 2). The apparent activation energy for the formation of each product was determined from Arrhenius plots, yielding $22 \mathrm{kcal} / \mathrm{mol}$ for MIBE and $24 \mathrm{kcal} / \mathrm{mol}$ for isobutene. The activation energy of $19 \mathrm{kcal} / \mathrm{mol}$ for DME was obtained by theoretical calculations [10].

Table 2 demonstrates that the MIBE yields at $498 \mathrm{~K}$ increased, whereas isobutene yields decreased with total alcohol pressure increasing from 7.8 to $240.7 \mathrm{kPa}$. For example, $0.156 \mathrm{~mol} / \mathrm{kg}$ cat $/ \mathrm{hr}$ MIBE at $7.8 \mathrm{kPa}$ kept increasing with pressure to 0.702 $\mathrm{mol} / \mathrm{kg}$ cat $/ \mathrm{hr}$ at $240.7 \mathrm{kPa}$, while isobutene at $7.8 \mathrm{kPa}(3.525 \mathrm{~mol} / \mathrm{kg}$ cat $/ \mathrm{hr})$ exhibited a decreasing trend to $0.335 \mathrm{~mol} / \mathrm{kg}$ cat $/ \mathrm{hr}$ at $240.7 \mathrm{kPa}$. 
Table 2. Product space time yields ( $\mathrm{mol} / \mathrm{kg} \mathrm{cat} / \mathrm{hr}$ ) and selectivity $(\%)$ in the reaction of $\mathrm{MeOH} / \mathrm{i}-\mathrm{BuOH}(2: 1 \mathrm{molar}$ ratio) at $15.6 \mathrm{~mol} / \mathrm{kg}$ cat $/ \mathrm{hr}$ alcohols, $186 \mathrm{~mol} / \mathrm{kg}$ cat $/ \mathrm{hr}$ carrier gas and $498 \mathrm{~K}$ over $(\mathrm{HO})_{3} \mathrm{Zr}-\mathrm{O}_{3} \mathrm{SOCH}_{2} \mathrm{CH}_{2} \mathrm{OSO}_{3}-\mathrm{Zr}(\mathrm{OH})_{3}$-derived catalyst. ${ }^{\mathrm{a}}$

\begin{tabular}{|c|c|c|c|c|c|c|c|c|}
\hline $\begin{array}{l}\text { Total pressure } \\
\qquad(\mathrm{kPa})\end{array}$ & $\begin{array}{l}\text { MeOH pressure } \\
\quad(\mathrm{kPa})\end{array}$ & $\begin{array}{l}\text { i-BuOH pressure } \\
(\mathrm{kPa})\end{array}$ & MIBE & Isobutene & DIBE & DTBE & $\begin{array}{c}\text { MIBE } \\
\text { selectivity (\%) }\end{array}$ & $\begin{array}{l}\text { Isobutene } \\
\text { selectivity (\%) }\end{array}$ \\
\hline $\begin{array}{l}101.3 \\
691.0\end{array}$ & $\begin{array}{r}5.2 \\
35.7\end{array}$ & $\begin{array}{r}2.6 \\
17.8\end{array}$ & $\begin{array}{l}0.156 \\
0.393\end{array}$ & $\begin{array}{l}3.525 \\
3.201\end{array}$ & $\begin{array}{l}--- \\
---\end{array}$ & $\begin{array}{l}--- \\
---\end{array}$ & $\begin{array}{r}4.2 \\
10.9\end{array}$ & $\begin{array}{l}95.8 \\
89.1\end{array}$ \\
\hline 1036.5 & 53.5 & 26.7 & 0.521 & 2.972 & ---- & 0.012 & 14.9 & 84.8 \\
\hline 1727.5 & 89.1 & 44.6 & 0.557 & 2.197 & ---- & 0.006 & 20.2 & 79.6 \\
\hline 2418.5 & 124.8 & 62.4 & 0.675 & 1.473 & ---- & 0.007 & 31.3 & 68.4 \\
\hline 3109.5 & 160.5 & 80.2 & 0.702 & 0.335 & 0.015 & $5 \quad 0.007$ & 66.3 & 31.6 \\
\hline
\end{tabular}

a Steady state activities were readily achieved within $2 \mathrm{hr}$ of initiation of alcohol injection or after altering a reaction variable such as pressure. Extended testing of the $(\mathrm{HO})_{3} \mathrm{Zr}-\mathrm{O}_{3} \mathrm{SOCH}_{2} \mathrm{CH}_{2} \mathrm{OSO}_{3}-\mathrm{Zr}(\mathrm{OH})_{3}$-derived catalyst under each condition was carried out for 8-12 hr. No catalyst deactivation was observed over several hundred hours of testing.

The data in Table 2 are consistent with the Langmuir-Hinshelwood kinetic laws [8b], $\mathrm{v}_{\mathrm{MIBE}}=k_{4} K_{\mathrm{M}} p_{\mathrm{M}} K_{\mathrm{B}} p_{\mathrm{B}} /\left(1+K_{\mathrm{M}} p_{\mathrm{M}}+K_{\mathrm{B}} p_{\mathrm{B}}\right)^{2}$ and $\mathrm{v}_{\text {Isobutene }}=k_{3} K_{\mathrm{B}} p_{\mathrm{B}} /\left(1+K_{\mathrm{B}} p_{\mathrm{B}}+K_{\mathrm{M}} p_{\mathrm{M}}\right)^{2}$ that were derived on the basis of Reactions 1 and 2 occurring on dual acid sites [8b]. The values of constants fitting the data of Table 2 were $k_{3}=33.1 \mathrm{~mol} / \mathrm{kg}$ cat $/ \mathrm{hr}, k_{4}=3.2$ $\mathrm{mol} / \mathrm{kg}$ cat $/ \mathrm{hr}, K_{\mathrm{M}}=0.035 \mathrm{kPa}^{-1}$ and $K_{\mathrm{B}}=0.086 \mathrm{kPa}^{-1}$.

The kinetic behavior of Equation 1 showed that isobutanol partial pressure $\left(p_{\mathrm{B}}\right)$ promoted the $\mathrm{MeOH} / \mathrm{i}-\mathrm{BuOH}$ coupling to $\mathrm{MIBE}$, whereas the kinetic behavior of Equation 2 indicated that increasing isobutanol pressure $\left(p_{\mathrm{B}}\right)$ very strongly suppressed its dehydration, and the kinetic order became negative at high $p_{\mathrm{B}}[9]$. At low alcohol partial pressures $\left(p_{\mathrm{M}}=5.2 \mathrm{kPa}\right.$ and $\left.p_{\mathrm{B}}=2.6 \mathrm{pKa}\right)$, high selectivity of isobutene $(95 \%)$ is ascribed to a significant fraction of unoccupied acid sites on the surface of the $\left(\mathrm{HSO}_{4}\right)_{2}-2 \mathrm{ZrO}_{2}$ catalyst. These free acid sites are considered to promote the dehydration of adsorbed 
isobutanol to isobutene according to the dual site elimination mechanism of Equation 2, whereby one site adsorbs the reacting alcohol and the second site is an acceptor for the product water [8b,9]. At high alcohol partial pressures, the fraction of acid sites occupied by alcohol molecules approaches unity, and the catalyst favors MIBE formation. A maximum selectivity of MIBE reached $68 \%$ at $240 \mathrm{kPa}$ total alcohol pressure $\left(p_{\mathrm{M}}=160\right.$ $\mathrm{kPa}$ and $p_{\mathrm{B}}=80 \mathrm{kPa}$ ) at the reaction temperature of $498 \mathrm{~K}$. The ratio of $\mathrm{MIBE} /$ isobutene increased with increasing alcohol pressure even at constant $p_{\mathrm{B}} / p_{\mathrm{M}}$. Moreover, the effect of pressure was found to be reversible, i. e. when alcohol pressure was decreased to its original value, isobutene production increased and MIBE decreased to their original rates.

The butene formed over the present $\left(\mathrm{HSO}_{4}\right)_{0.84}-\mathrm{ZrO}_{2 \text {,surf }}$ catalyst was pure isobutene, whereas over other catalysts, such as $\mathrm{H}$-montmorillonite and H-ZSM-5, products involved significant amounts of $\mathrm{n}$-butene and cis- and trans-2-butene along with the isobutene. The highly concentrated Brr nsted acid sites on this catalyst effectively catalyzed removal of $\mathrm{OH}$ from the alcoholic carbon and of $\mathrm{H}$ from the neighboring carbon, resulting in isobutene formation. On the other hand, the single Brr nsted acid site on the surface of other catalysts was associated with carbenium ion chemistry [12], which leads to butene rearrangement in isobutanol dehydration $[12,13]$.

In conclusion, the novel heterogeneous catalyst derived form the $(\mathrm{HO})_{3} \mathrm{Zr}$ $\mathrm{O}_{3} \mathrm{SOCH}_{2} \mathrm{CH}_{2} \mathrm{OSO}_{3}-\mathrm{Zr}(\mathrm{OH})_{3}$ precursor effectively catalyzes MIBE formation at high pressures and favored isobutene production at low pressures. 


\section{ACKNOWLEDGEMENT}

We thank Dr. T. H. Kalantar of the M.E. Pruitt Research Center, Dow Chemical Co., Midland, MI 48674 for providing the precursor salt that was used to prepare this catalyst.

\section{REFERENCES}

1. (a) K. Klier, in "Catalysis on the Energy Scene," Ed.: A. Kaliaguine and A. Mahay, Elsevier, Amsterdam (1984) 439; (b) K. Klier, R. G. Herman, and C. W. Young, Preprints, Div. Fuel Chem., ACS, 29(5) (1984) 273; (c) G. A. Vedage, P. B. Himelfarb, G. W. Simmons, and K. Klier, ACS Symp. Ser., 279 (1985) 295.

2. (a) J. G. Nunan, C. E. Bogdan, K. Klier, K. J. Smith, C. W. Young, and R. G. Herman, J. Catal., 116 (1989) 195; (b) J. G. Nunan, R. G. Herman, and K. Klier, J. Catal., 116 (1989) 222.

3. E. Tronconi, N. Ferlazzo, P. Forzatti, and I. Pasquon, Ind. Eng. Chem. Res., 26 (1987) 2122.

4. E. Tronconi, L. Lietti, P. Forzatti, and I. Pasquon, Appl. Catal., 47 (1989) 317.

5. R. G. Herman, K. Klier, O. C. Feeley, and M. A. Johansson, Preprints, Div. Fuel Chem., ACS, 39(2) (1994) 343.

6. T. H. Fleisch and P. C. Meurer, Fuel Technol. Manage., 6(4) (1996) 54.

7. Y. Ohno, T. Shikada, T. Ogawa, M. Ono, and M. Mizuguchi, Preprints, Div. Fuel Chem., ACS, 42(2) (1997) 705. 
8. (a) J. Nunan, K. Klier, and R. G. Herman, J. Chem. Soc., Chem. Commun. (1985) 676; (b) J. G. Nunan, K. Klier, and R. G. Herman, J. Catal., 139 (1993) 406; (c) O. C. Feeley, Q. Sun, R. G. Herman, M. A. Johansson, L. Lietti, and K. Klier, Catal. Lett., 35 (1995) 13.

9. K. Klier, R. G. Herman, M. A. Johansson, and O. C. Feeley, Preprints, Div. Fuel Chem., ACS, 37(1) (1992) 236.

10. K. Klier, H. H. Kwon, R. G. Herman, R. A. Hunsicker, Q. S. Ma, and S. J. Bollinger, in " $12^{\text {th }}$ Intern. Congr. Catal.," Ed.: A. Corma, F. V. Melo, A. Mendioroz, and F. L. S. Fierro, Elsevier, Amsterdam, (2000) 3447.

11. J. Long and B. Munson, J. Am. Chem. Soc., 95 (1973) 2427.

12. O. C. Feeley, M. A. Johansson, R. G. Herman, and K. Klier, Preprints, Div. Fuel Chem., ACS, 37(4) (1992) 1817.

13. S. Kotsarenko and L. V. Malysheva, Kinet. Catal., 24 (1983) 877. 